\title{
Työn ja työelämän opintokokonaisuus Jyväskylän yliopistossa
}

\author{
Timo Anttila
}

Jyväskylän yliopistossa työn ja työelämän opetusta ja tutkimusta tehdään monissa tiedekunnissa ja oppiaineissa. Tässä katsauksessa kuvaan työhön ja työelämään liittyvää opetusta lähinnä sosiaalitieteiden näkökulmasta. Toimin yhteiskuntatieteiden ja filosofian laitoksen koordinoiman Työn ja työelämän tutkimus -moduulin vastuuhenkilönä. Kyseessä on 25-41 opintopisteen laajuinen erillisopintokokonaisuus, joka on vapaa kaikille Jyväskylän yliopiston opiskelijoille. Kurssipaketti on ollut ohjelmassa useampia vuosia, ja se on mukana myös uudessa vuoteen 2023 kestävässä opetussuunnitelmassa. Opetusohjelman kuvauksen mukaan se perehdyttää työn ja työelämän politiikkoihin, käytäntöihin ja muutokseen. Tavoitteena on antaa opiskelijoille valmiuksia ymmärtää niin kotimaisia kuin kansainvälisiä työmarkkinajärjestelmiä, keskeisiä työn teorioita sekä työelämän historiaa ja nykytrendejä.

Yliopistossa opetus määrittyy usein tutkimusperinteiden pitkien linjojen mukaiseksi. Myös Jyväskylässä työelämän tutkimus ja opetus on muokkautunut useamman vuosikymmenen aikana ja kursseista voi hyvin havaita aiempien opettajasukupolvien työn jäljen. Opetuksessa näkyy työpoliittinen ja työn sosiologinen perinne sekä työn muutoksia empiirisesti - usein pitkillä tilastollisilla aineistosarjoilla - havainnoiva empiirinen tutkimus. Tampereen yliopiston työelämän opetus, jota Pasi Pyöriä kuvaa tässä numerossa, on mielenkiintoisella tavalla samaa juurta. Tämä johtunee tutkijoiden ja opettajien pitkästä yhteises- tä historiasta, yhteisistä tutkimushankkeista ja ristikkäin tapahtuneesta liikkuvuudesta. Sekä Jyväskylässä että Tampereella opetus perustuu monitieteisissä tutkimusryhmissä tehtyyn empiiriseen tutkimukseen.

\section{Työn ja työelämän opintokokonaisuuden ydinopinnot}

Kurssipaketin ydinopinnoissa (15 opintopistettä) painottuu sekä sosiologinen että yhteiskuntapoliittinen näkökulma työhön. Ydinopinnot koostuvat vastuullani olevista luentokursseista Työ ja työpolitiikka ja Työmarkkinat ja -prosessit sekä näiden teemoja syventävästä kirjapaketista Työn ja työmarkkinoiden muutokset. Työpolitiikka-kurssi ottaa nimensä mukaisesti yhteiskuntapoliittisen tarkastelukulman työelämään. Kurssin luennot ovat vaihdelleet vuosittain, mutta keskeisiä teemoja ovat työllisyyteen ja työttömyyteen liittyvät politiikat. Eräs keskeisistä kysymyksistä on se, miten talouspoliittiset teoriavirtaukset vaikuttavat keskusteluun työttömyydestä. Kurssilla keskustellaan esimerkiksi sitä, miten ja miksi eri maat noudattavat erilaista työllisyyspolitiikkaa. Eroja voidaan selittää muun muassa kapitalismin eri variaatioilla tai erilaisilla työllisyysregiimeillä. Suomi on osa pohjoismaista työmarkkinamallia, jonka erityispiirteitä sekä onnistumisia ja ongelmia vertaillaan muihin malleihin. Kurssille on pyritty saamaan myös työmarkkinajärjestelmää ja käytännön työmarkkinapolitiikkaa hallitsevia 
luennoitsijoita. Tavoitteena on, että opiskelijat hahmottavat työmarkkinoiden neuvottelujärjestelmän rakennetta ja oppivat myös ymmärtämään työmarkkinapolitiikan sanastoa ja kielioppia.

Työpolitiikkaan kuuluu perinteisesti työmarkkinoiden rakenteiden pohdinta ja kysymykset siitä, millaisia jakoja työmarkkinoilla tapahtuu esimerkiksi sukupuolen ja luokkaaseman suhteen. Viime vuosina työelämän tasa-arvoon liittyvät teemat ovat olleet luentosarjan keskeistä sisältöä. Palkkatyön tasaarvokysymysten lisäksi kurssilla korostetaan myös palkattoman työn jakautumista yhteiskuntapoliittisesti tärkeänä kysymyksenä. Luentosarjalla käsitellään siis myös kodeissa tapahtuvan palkattoman työn jakautumista Suomessa sekä kansainvälisesti.

Työmarkkinat ja -prosessit -kurssi on luonteeltaan sosiologinen. Kurssin teoreettisena lähtökohtana on työprosessitutkimuksen pitkä perinne. Työprosessiteoriaa soveltavat tutkijat ovat erityisen kiinnostuneita tuotannon sosiaalisista suhteista. Usein työprosessitutkimus kohdistuu työpaikan lattiatasolle ja tarkastelee esimerkiksi työpaikkojen konflikteja, kontrollia, suostumusta tai sääntelyä. Kurssi etenee historiallisen kaaren mukaisesti lähtien liikkeelle esiteollisen vaiheen ja teollisen vaiheen murroksesta, jossa työ vähittäin vakiintui vallitsevaan muotoonsa ja tämän jälkeen kuvaten työn uudelleenmuotoutuminen siirryttäessä jälkiteolliseen tieto- ja palveluvaltaiseen talouteen.

Luennoilla pyritään osoittaman työn ja työelämän muutos, mutta myös kyseenalaistamaan ajatus täydellisestä muutoksesta. Ajattelemme usein, että esimerkiksi teollinen pakkotahtinen taylorisoitu työ on jäänyt taakse. Käytännössä voimme kuitenkin löytää taylorisoitua pakkotahtista ja standardoitua työtä aivan uusista paikoista, vaikkapa palvelusektorilta. Luennoilla pyritään myös muutoin kannustamaan opiskelijoita katsomaan kriittisesti keskustelua työelämän muutoksesta. Käymme esimerkkien avulla läpi työelämän myyttejä ja pohdimme, miten muutosta voisi empiirisesti havainnoida erilaisin aineistoin. Yksi esimerkki tästä on keskustelu pätkätöistä tai muista epätyypillisistä työsuhteista. On tärkeä havaita, että tutkimusaineistot eivät välttämättä tue julkista keskustelua, mutta kenties olennaisempaa on pohtia, miksi näiden tuottamat kuvat poikkeavat.

Sosiologiseen työn tutkimuksen otteeseen kuuluu myös kriittinen tulkinta työn muutoksesta. Työprosessitutkimus on tuottanut vuosikymmeniä erilaisia teoreettisia tulkintoja työelämän muutoksesta, esimerkiksi työn köyhtymisestä tai rikastumisesta. Usein oletuksena on, että varsinkin uudet johtamisopit vaikuttavat työn muutokseen ja sen suuntaan. Managerialistiset opit matkaavat maasta toiseen ja muokkaavat työelämää siten yhdenmukaiseksi. Toisaalta eri mailla on omat työelämän instituutionsa ja kulttuuriset siteet, jotka tekevät maista erityisiä. Suomalaisen tai pohjoismaisen työelämän erityisyyttä voidaan havainnoida empiirisin aineistoin, joten kurssien keskeinen sisältö onkin maiden välisten erojen tai yhtäläisyyksien havainnointi. Viime vuosina kursseilla on keskusteltu myös siitä, miten ja miksi uudet johtamisopit siirtyvät sektorilta toiselle. Esimerkiksi julkisten palvelujen tehostamistoimet yksityiseltä sektorilta lainattujen oppien mukaisesti ja uusi julkisjohtaminen ovat olleet kiinnostava keskustelunaihe.

\section{Opintokokonaisuuden vapaavalinnaiset opinnot}

Kurssipakettiin sisältyy pakollisten kurssien lisäksi myös vapaavalintaisia kursseja. Valittavina ovat englanninkielinen kurssit Family, Care and Social Policy ja Migration Policy sekä suomenkieliset kurssit Taloussosiologia ja Henkilöstöjohtaminen.

Family, Care and Social Policy-kurssi keskittyy vertailevalla otteella kansainväliseen keskusteluun perheestä, hoivasta, työstä ja sosiaalipolitiikasta. Kurssi linkittyy työelämän tutkimukseen tuomalla esiin, miten eri malleissa 
hoivavastuut perheen ja valtion välillä ovat yhteydessä työmarkkinoiden rakentumiseen ja miten ne vaikuttavat kansalaisten tasa-arvoon ja hyvinvointiin. Migration policy-kurssi linkittyy työelämän ja työmarkkinoiden kysymyksiin työvoiman kansainvälisen ja kansallisen liikkuvuuden teemalla. Kurssin keskeinen kysymys on, miten työvoiman liikkuvuuteen liittyvä teoria ja politiikka muuntuvat ja sopeutuvat aivan uudenlaisissa maahanmuuttoon vaikuttavissa globaaleissa, taloudellisissa ja poliittisissa muutoksissa.

Jyväskylän yliopiston kauppakorkeakoulun tarjoamalla Henkilöstöjohtamisen kurssilla lähestytään työn organisoinnin muutoksia johtamisen näkökulmasta. Tavoitteena on, että kurssin myötä opiskelijat ymmärtävät, miten historiallisesti vaihtuvat käsitykset johtamisesta vaikuttavat henkilöstöjohtamiseen käytännössä, ja osaavat myös arvioida henkilöstöjohtamisen merkitystä organisaatioiden toiminnassa. Taloussosiologian kurssin keskeinen teema on talouden ja työmarkkinoiden kiinnittyminen sosiaaliseen ympäristöön. Kurssilla käsitellään esimerkiksi tuotannon ja työn joustavoitumisen tendenssiä ja sitä, miksi samalla verkostojen ja luottamuksen merkitys kasvaa taloudellisessa toiminnassa.

Työ ja työmarkkinat ovat julkisen keskustelun kestoaiheita. Työelämän muutos ja työelämään siirtyminen ovat perinteisesti olleet opiskelijoita askarruttavia asioita. Tällä hetkellä näyttää siltä, että monitieteisellä, työelämää eri näkökulmista katsovalla opetuksella on hyvä kysyntätilanne. Kurssipaketin ydinopintoihin ilmoittautuu opiskelijoita etenkin yhteiskuntatieteistä, mutta monet tulevat myös humanististen tieteiden, kasvatustieteen ja kauppatieteen oppiaineista. Näin ollen voidaan olettaa, että Jyväskylä lähettää työelämään tuota työelämää analyyttisesti ja kriittisesti katsovia asiantuntijoita.

\section{Kirjoittaja}

Timo Anttila, YTT, dos., yliopistonlehtori, Jyväskylän yliopisto, sähköposti: timo.anttila@jyu.fị 